\title{
Effect of Dormex, Fructose and Methionine Spraying on Bud Dor- mancy Release of "Superior" Grapevines
}

\author{
Asmaa A. Mohamed ${ }^{1}$ and Fatma El-Zahraa M. Gouda ${ }^{2}$ \\ ${ }^{1}$ Viticulture Dept., Hort. Res. Inst., Agric. Res. Center, Giza, Egypt. \\ E-mail: Ticcuie-culture@yahoo.com \\ ${ }^{2}$ Pomology Department, Fac. Agric., Assiut University \\ E-mail: Fatma.gouda@agr.au.edu.eg
}

Received on: 6/2/2017

Accepted for publication on: 27/2/2017

\begin{abstract}
This study was carried out during the two successive seasons 2015 and 2016 on 13 years old "Superior" grapevines to study the effect of spraying fructose $(3,5 \%)$, methionine $(3,5 \%)$ and hydrogen cyanamide $5 \%$ (Dormex) on bud dormancy release of "Superior" grapevines. Cyanamide is frequently used for grape bud dormancy release. However, those chemicals are potentially harmful to humans. In this study, we used substances that are less toxic to the environment and grape growers, such as fructose and methionine to determine their effects on "Superior" grape bud break. All treatments significantly improved the percentage of bud break, fruiting buds and yield, as well as the advancement of the harvest date and improving the berry quality compared to untreat ones (control). Also, all treatments induce gradually increased bud contents of IAA and $\mathrm{GA}_{3}$ and a gradual decrease of ABA from treated date towards buds burst compared to untreated ones. Dormex spraying gave the highest values of studied traits compared to other treatments. No significant differences were found among $5 \%$ dormex and 3\% fructose spraying. Hence, 3\% fructose shows potential for use as a commercial bud break and improves superior grapes fruiting.
\end{abstract}

Keywords: Dormancy, Grapevines, Fructose, Methionine, Dormex.

\section{Introduction}

Grape is the most important fruit crop in the world. It is considered as one of the most popular fruit crop in Egypt. Warm winters in many regions often limit the productivity of grape because of insufficient winter chilling (George and Nissen, 1990 and El-Salhy, 2002). Under these conditions, lack of winter chilling may result in uneven and irregular bud burst as well as increment of dormant buds, reduction of flower buds, extended flowering and delayed fruit maturity (George and Nissen, 1990; El-Sese and Mohamed, 2003 and Mohamed and Omran, 2004).
Bud dormancy in woody perennials is a complex process that enables plants to survive long periods of adverse conditions, including the extremes of drought, cold and heat, and is characterized by growth cessation, arrest of cell division, and reduced metabolic and respiratory activity (Arora et al., 2003). During dormancy, visible growth is suspended but developmental changes can still occur (Saure, 1985) and buds are physiologically and biochemically active. Numerous physiological changes such as respiration rate, growth regulators, carbohydrate metabolism, water content and other 
compounds that thought to be involved in dormancy release were estimated to analyze the control of dormancy (Trejo-Martinez et al., 2009). Many investigations have been conducted to artificially interrupt the dormancy in grapevines with synthetic chemicals (Shulman et al., 1983; Lin and Wang, 1985; Nir et al., 1988; Zelleke and Kliewer, 1989; Dookoozlian and Williams, 1995). Among such products, hydrogen cyanamide $\left(\mathrm{H}_{2} \mathrm{CN}_{2}\right)$ has been the most effective bud breaking agent for field use (Zelleke and Kliewer, 1989; ElSabrout, 1998 and El-Salhy, 2002). It was very effective and leads to early and vigorous vegetative growth. Spraying dormex significantly increased the endogenous bud IAA and giberellic acid contents, and significantly reduced bud ABA contents compared to the control. Spraying with dormex $(5 \%)$ gave the highest bud burst, yield and berry quality of grape cv. Flame Seedless (ElSabrout, 1998). Those cyanamides are known to have a negative impact on grape growers' health and the environment. Nevertheless, these bud breaking inducing agents are not authorized for use in organic cultivation (Settimi et al., 2005). Hence, there is an urgent need to develop dormancy release agents that pose no health risks to humans and for organic farming products.

Sugar and methionine, may be utilized as bud break agents as they are safer than cyanamides. The sugar shows no toxic effects or mutagenicity and is a component of human food (Matsuo and Izumori, 2006). Methionine has been found to have no adverse effects on the human body
(Garlick, 2006). The sugar improved the percentage of bud break when applied at $1 \%$ concentration. When the concentration was increased to $3 \%$, percentage, bud break was increased. On the other hand, methionine induces bud break and slightly improved bud break at $3 \%$ concentration compared to control (Madhab et al., 2011).

The objective of this study was to examine the effect of environmentally friendly compounds, such as fructose sugar and methionine, on the bud dormancy release and fruiting of Superior grapevines growing under hot climates.

\section{Materials and Methods}

This study was carried out during 2015 and 2016 seasons on 54 uniforms in vigour 13-years old Superior grapevines soil grown in sandy soil at Assiut Agriculture Research Station, ARC, Assiut Governorate. All the selected vines are planted at $1.75 \times 2.75$ $\mathrm{m}$ apart. The vines were pruned during the $1^{\text {st }}$ week of January for the two seasons of the study leaving 84 eyes on the basic of 6 fruiting canes $x$ 12 eyes plus 6 renewal spurs $x 2$ eyes with the assistance of double $\mathrm{T}$ and irrigated by flooding irrigation system. All the selected vines received regular and horticultural practices that already applied in the vineyard except those dealing with using dormancy breakages. This study included the following six treatments, as follows: trol).

1- Spraying with water (con-

2- Spraying with $5 \%$ hydrogen cyanamide (Dormex).

3- Spraying with 3\% methionine. 

ine.

4- Spraying with 5\% methion-

5- Spraying with 3\% fructose.

6- Spraying with 5\% fructose.

The experiment was designed as randomized complete block design (RCBD) with three replicates for each treatment, one vine per each.

Tap water was used for dilution and Triton B was applied at $1 \%$ to all spray solutions as a wetting agent. Foliar spray was carried out using a hand sprayer until drop point to dormant buds. All treatments were applied once at $2^{\text {nd }}$ January.

During both seasons, the following measurements were determined:

1-Date of bud burst and its percentage: Date of bud burst was recorded and then the number of bursted out buds/vine was recorded, then the percentage was calculated by dividing the number of bud burst/vine by the total number of buds per vine which is left at pruning at weekly intervals along the bursting period.

2-Yield components and berry quality: All harvest dates, the yield per vine was recorded in terms of weight $(\mathrm{kg})$ and number of cluster. Harvest date per treatment at least TSS reached $14 \%$ was recorded. Percentage of shot berries and weight of 25 berries and berry dimension were recorded. Berry chemical quality in terms of TSS, total acidity, TSS/acid ratio and reducing sugars were determined as outlined in A.O.A.C. (2000).

3-Bud hormonal content: Bud samples were collected, 15-days intervals, beginning from 7 January up to 18 February for determining the metabolic changes in the hormonal content in buds. Buds were randomly sampled and immediately transported to the laboratory. Bud samples were taken from each vine of each treatment and were analyzed for endogenous levels of gibberelic acid $\left(\mathrm{GA}_{3}\right)$, indole-3-acetic acid (IAA) and abscisic acid (ABA). The extraction and purification were made following the method of Kettner and Doerffling (1995).

Samples (1.0 g) were collected, from each treatment, and homogenized, at $4^{\circ} \mathrm{C}$, in $80 \%$ methanol containing $0.1 \mathrm{~g} \mathrm{l}^{-1}$ an antioxidant, butylated hydroxyl toluene (BHT). They were extracted at $4^{\circ} \mathrm{C}$ in dark for $72 \mathrm{~h}$ with subsequent change of solvent. The extracted samples were centrifuged and the supernatant was reduced to aqueous phase using rotary thin film evaporator (RFE). The $\mathrm{pH}$ of aqueous phase was adjusted to 2.53.0 and partitioned three times with $1 / 3$ volume of ethyl acetate. The ethyl acetate phase was dried down completely using RFE. The dried sample was re-dissolved in $1 \mathrm{ml}$ of methanol $(100 \%)$ and was analyzed on HPLC (Shimadzu, C-R4A Chromatopac; SCL-6B system controller) using UV detector and $\mathrm{C}_{18}$ column $(39 \times 300 \mathrm{~mm})$. For identification of hormones, $100 \mu \mathrm{l}$ samples filtered through 0.45 Millipore filters were injected into column. Pure IAA and $\mathrm{GA}_{3}$ (Sigma, USA) were used as standards for identification and quantification of these hormones. The identification was made on the basis of retention time and peak area of the standards. Methanol, acetic acid and water (30:1:70, respectively) were used as a mobile phase. The flow rate was adjusted at $0.5 \mathrm{ml} \mathrm{min}{ }^{-1}$ with an average time for $15 \mathrm{~min}$ sample $^{-1}$. 
The wave length used for the detection of IAA was $280 \mathrm{~nm}$, while for $\mathrm{GA}_{3}$ was $254 \mathrm{~nm}$. For ABA, samples were injected onto a $\mathrm{C}_{\mathbf{1 8}}$ column and eluted with a linear gradient of methanol (30-70\%), containing $0.01 \%$ acetic acid, at a flow rate of $0.8 \mathrm{ml} \mathrm{min}^{-1}$. The retention time of ABA was determined by using authentic standards, monitoring the elution of standard at $254 \mathrm{~nm}$.

Statistical analysis was done (Mead et al., 1993) and treatments means were compared using new L.S.D.

\section{Results}

\section{Environmental conditions:}

Data of monthly temperatures and relative humidity as average during the two seasons of this study are presented in Table (1). During the two experimental seasons the mean monthly temperature ranged from $16.60 \& 15.25^{\circ} \mathrm{C}$ in December to $18.50 \& 19.80^{\circ} \mathrm{C}$ in Marsh, which is insufficient for winter chilling to overcome dormancy. In this regard, Weaver (1976) reported that grapes usually require a winter rest period of about 2 months, with an average daily mean temperature below $50^{\circ} \mathrm{F}$ $\left(10^{\circ} \mathrm{C}\right)$, which mean insufficient cold. Thus, artificial means to compensate the lack of natural chilling becomes a dominant tool to produce economic grape yield in warm winter regions (Poni et al., 1990).

Table 1. Monthly weather, maximum, minimum and mean of temperature and relative humidity of $2014 / 2015$ and $2015 / 2016$ seasons.

\begin{tabular}{|c|c|c|c|c|c|c|c|c|}
\hline \multirow{3}{*}{ Month } & \multicolumn{4}{|c|}{$\mathbf{2 0 1 4 / 2 0 1 5}$} & \multicolumn{4}{c|}{$\mathbf{2 0 1 5 / 2 0 1 6}$} \\
\cline { 2 - 6 } & \multicolumn{2}{|c|}{ Temperature $\left.\mathbf{(}^{\circ} \mathbf{C}\right)$} & \multirow{2}{*}{$\begin{array}{c}\text { Relative } \\
\text { humidity }\end{array}$} & \multicolumn{2}{c|}{ Temperature ( $\left.{ }^{\circ} \mathbf{C}\right)$} & Max. & Melative \\
& Max. & Min. & Mean & & Mean & humidity \\
\hline Nov. & 27.6 & 13.4 & 20.5 & 55.0 & 28.0 & 13.4 & 20.7 & 53.0 \\
\hline Dec. & 22.4 & 10.8 & 16.6 & 64.0 & 23.1 & 7.4 & 15.25 & 62.0 \\
\hline Jan. & 20.0 & 5.4 & 12.7 & 62.5 & 23.8 & 8.0 & 15.9 & 65.0 \\
\hline Feb. & 23.2 & 10.2 & 16.7 & 66.0 & 26.2 & 7.0 & 16.6 & 67.0 \\
\hline Mar. & 26.8 & 10.2 & 18.5 & 59.5 & 26.2 & 13.4 & 19.8 & 56.0 \\
\hline Apr. & 25.8 & 10.0 & 17.9 & 55.5 & 33.4 & 12.4 & 22.9 & 52.5 \\
\hline
\end{tabular}

After, Assiut Weather Station.

\section{Behaviour of buds:}

The effect of dormex, methionine and fructose spraying on bud burst and fruiting buds percentage and date of bud burst of Superior grapevines during 2015 and 2016 seasons are shown in Table (2). As a general view it can noticed that all treatments significantly increased the percentage of bud burst and fruiting buds, as well as the advancement of bud bust and blooming over the check treatment (control). Using dormex or fructose was significantly superior to use methionine in breaking dormancy and enhancing percentage of bud break and fruiting buds. The highest bud burst percentages (63.30 \& 67.66\%) were recorded on the vines that received dormex at 5\%, followed by fructose at 3\% spraying (58.00 \& 61.33\%). The fruiting buds percentage were $50.33 \& 51.66 \%$ and $46.66 \& 47.33 \%$ due to dormex at $5 \%$ and fructose at 3\% spraying during the two studied seasons, respectively. 
The corresponding date of bud burst was $20 \& 19$ Feb. and $19 \& 20$ Feb., respectively. On other hand, untreated vines had reduced percentages of bud burst $(40.33 \& 45.00 \%)$ fruiting buds $(32.00 \& 33.66 \%)$ and delayed bud burst (18 \& 20 Mar.) during the two studied seasons, respectively.
The increment of bud burst percentage were $56.96 \& 50.36 \%$ and $43.81 \& 36.28 \%$, fruiting bud percentage were $57.28 \& 53.48 \%$ and $45.81 \& 40.61 \%$ and bud burst was advanced by $26 \& 30$ days and $27 \&$ 30 days due to dormex and fructose at $3 \%$ spraying compared to unsprayed vines during the two studied seasons, respectively.

Table 2. Effect of dormex, fructose and methionine spraying on bud behavior and date of bud burst of superior grapevines during 2015 and 2016 seasons.

\begin{tabular}{|l|c|c|c|c|c|c|}
\hline \multirow{2}{*}{ Treatment } & \multicolumn{2}{|c|}{ Bud burst \% } & \multicolumn{2}{c|}{ Fruiting buds \% } & \multicolumn{2}{c|}{ Date of bud } \\
\cline { 2 - 7 } & $\mathbf{2 0 1 5}$ & $\mathbf{2 0 1 6}$ & $\mathbf{2 0 1 5}$ & $\mathbf{2 0 1 6}$ & $\mathbf{2 0 1 5}$ & $\mathbf{2 0 1 6}$ \\
\hline Control & 40.33 & 45.00 & 32.00 & 33.66 & $18 \mathrm{Mar}$. & $20 \mathrm{Mar}$. \\
\hline Dormex 5\% & 63.30 & 67.66 & 50.33 & 51.66 & $20 \mathrm{Feb}$. & $19 \mathrm{Feb}$. \\
\hline Fructose 3\% & 58.00 & 61.33 & 46.66 & 47.33 & 19 Feb. & 20 Feb. \\
\hline Fructose 5\% & 53.33 & 58.33 & 43.66 & 40.00 & $24 \mathrm{Feb}$. & $22 \mathrm{Feb}$. \\
\hline Methionine 3\% & 52.66 & 59.33 & 41.00 & 38.33 & 23 Feb. & 28 Feb. \\
\hline Methionine 5\% & 45.33 & 51.33 & 40.00 & 44.66 & 20 Feb. & 23 Feb. \\
\hline LSD at 5\% & 2.89 & 2.74 & 2.69 & 2.40 & & \\
\hline
\end{tabular}

\section{Yield components:}

Data in Table (3) illustrated the effect of different breaking dormancy treatments on number of cluster, cluster weight and yield of superior grapevines during 2015 and 2016 seasons.

All breacking dormancy treatments significantly increased the number and weight of cluster, consequently significantly increased yield/vine compared to unspray ones (control) in both the two studied seasons. Dormex or fructose at 3\% was most effective compared to other treatments. No significant promotion was detected among dormex and fructose at 3\%. From economical point of view, the heaviest yield was on vines that sprayed with dormex $(8.36 \& 8.85 \mathrm{~kg} / \mathrm{vine})$ and fructose at $3 \%$ (8.43 \& $8.38 \mathrm{~kg} /$ vine) during the two studied seasons, respectively. The untreated vines produced the lighest ones $(5.78 \& 6.16 \mathrm{~kg} / \mathrm{vine})$ in both seasons, respectively. Then, the increment percentage of yield/vine were $44.64 \& 43.67 \%$ and $45.85 \&$ $36.04 \%$ due to dormex and fructose at $3 \%$ spraying compared to unsprayed ones, during the two studied seasons, respectively.

In addition, date in the previous table indicated that spraying dormex, fructose or methionine cause advancing of harvesting date over unsprayed ones (control). The best advanced harvesting date was presented on vines that received dormex or fructose at 3\% where, they were harvested about three weeks early compared to control. Other treatment advanced the harvest date about two weeks. 
Table 3. Effect of dormex, fructose and methionine spraying on number of cluster, cluster weight, yield and harvesting date of superior grapevines during 2015 and 2016 seasons.

\begin{tabular}{|l|c|c|c|c|c|c|c|c|}
\hline \multirow{2}{*}{ Treatment } & \multicolumn{2}{|c|}{ Number of cluster } & \multicolumn{2}{c|}{ Cluster weight (g) } & \multicolumn{2}{c|}{ Yield (kg/vine) } & \multicolumn{2}{c|}{ Harvesting date } \\
\cline { 2 - 10 } & $\mathbf{2 0 1 5}$ & $\mathbf{2 0 1 6}$ & $\mathbf{2 0 1 5}$ & $\mathbf{2 0 1 6}$ & $\mathbf{2 0 1 5}$ & $\mathbf{2 0 1 6}$ & $\mathbf{2 0 1 5}$ & 2016 \\
\hline Control & 17.66 & 20.00 & 326.33 & 308.00 & 5.78 & 6.16 & 2 July & 4 July \\
\hline Dormex 5\% & 23.33 & 26.18 & 361.33 & 348.35 & 8.36 & 8.85 & 11 Jun. & 10 Jun. \\
\hline Fructose 3\% & 22.66 & 25.33 & 373.33 & 341.80 & 8.43 & 8.38 & 15 Jun. & 12 Jun. \\
\hline Fructose 5\% & 21.80 & 23.80 & 352.33 & 328.33 & 7.85 & 7.68 & 20 Jun. & 17 Jun. \\
\hline Methionine 3\% & 21.00 & 23.33 & 349.60 & 324.00 & 7.51 & 7.65 & 20 Jun. & 20 Jun. \\
\hline Methionine 5\% & 21.50 & 24.70 & 358.30 & 334.66 & 7.66 & 8.14 & 16 Jun. & 18 Jun. \\
\hline LSD at 5\% & 1.68 & 1.50 & 15.65 & 11.81 & 0.90 & 0.58 & & \\
\hline
\end{tabular}

\section{Berry quality:}

Data in Tables (4 \& 5) clearly show that spraying any rest breakages significantly increased weight, length and width of berry, whereas, it was significantly reduced the shot berries percentage over the unsprayed ones (control). However, with regarding to the chemical characteristics of the berries, dormex, fructose and methionine they were significantly enhaned the TSS, TSS/acid ratio and reducing sugars percentage and decreased the total acidity over the control. The best improvement of berry quality was associated with dormex or fructose at 3\% spraying. No significant improving was detected among dormex or fructose at 3\% spraying. The heaviest twenty five berry weight were $82.75 \& 81.20$ and $84.25 \& 80.44 \mathrm{~g}$ due to dormex and fructose at 3\% spraying, respectively, against $(73.60 \& 71.85 \mathrm{~g})$ on unsprayed ones, during the two studied seasons, respectively. Hence, the corresponding increment percentage of berry weight were (12.43 \& $13.01 \%)$ and $(14.47 \& 11.19 \%)$ compared to control, respectively.

On other hand, the lowest shot berries \% was (3.16\& 3.67) and $(3.30 \& 3.88 \%)$ due to dormex and fructose at 3\% spraying, against (9.84 $\& 10.23 \%$ ) on unsprayed ones during the two studied seasons, respectively. Thus, the corresponding reduction percentage reached $(67.89 \& 64.13 \%)$ and (66.46 \& 62.07\%), respectively.

Also, the highest values of TSS/acid ratio were $33.33 \& 33.07$ and $30.15 \& 29.38$ due to dormex and fructose at $3 \%$ spraying, against (22.66 \& 22.49) on unsprayed ones, during the two studied seasons, respectively. The corresponding increment percentage of TSS/acid were (47.09 \& 41.62) and (33.05 \& 30.64) compared to control, respectively. 
Table 4. Effect of dormex, fructose and methionine spraying on the weight of 25 berries, shot berries \%, berry length and berry width of superior grapes during 2015 and 2016 seasons.

\begin{tabular}{|l|c|c|c|c|c|c|c|c|}
\hline \multirow{2}{*}{ Treatment } & \multicolumn{2}{|c|}{$\begin{array}{c}\text { 25 berry weight } \\
(\mathbf{g})\end{array}$} & \multicolumn{2}{c|}{ Shot berries \% } & \multicolumn{2}{c|}{$\begin{array}{c}\text { Berry length } \\
\text { (cm) }\end{array}$} & \multicolumn{2}{c|}{$\begin{array}{c}\text { Berry width } \\
\text { (cm) }\end{array}$} \\
\cline { 2 - 9 } & $\mathbf{2 0 1 5}$ & $\mathbf{2 0 1 6}$ & $\mathbf{2 0 1 5}$ & $\mathbf{2 0 1 6}$ & $\mathbf{2 0 1 5}$ & $\mathbf{2 0 1 6}$ & $\mathbf{2 0 1 5}$ & $\mathbf{2 0 1 6}$ \\
\hline Control & 73.60 & 71.85 & 9.84 & 10.23 & 1.74 & 1.39 & 1.70 & 1.35 \\
\hline Dormex 5\% & 82.75 & 81.20 & 3.16 & 3.67 & 1.91 & 1.55 & 1.87 & 1.50 \\
\hline Fructose 3\% & 84.25 & 80.42 & 3.30 & 3.88 & 1.95 & 1.53 & 1.90 & 1.49 \\
\hline Fructose 5\% & 80.22 & 77.78 & 4.10 & 4.82 & 1.86 & 1.48 & 1.85 & 1.46 \\
\hline $\begin{array}{l}\text { Methionine } \\
\text { 3\% }\end{array}$ & 80.50 & 78.00 & 3.89 & 4.88 & 1.86 & 1.48 & 1.88 & 1.46 \\
\hline $\begin{array}{l}\text { Methionine } \\
\text { 5\% }\end{array}$ & 81.55 & 79.30 & 3.66 & 4.34 & 1.88 & 1.51 & 1.84 & 1.48 \\
\hline LSD at 5\% & 3.68 & 2.92 & 0.61 & 0.86 & 0.09 & 0.07 & 0.10 & 0.10 \\
\hline
\end{tabular}

Table 5. Effect of dormex, fructose and methionine spraying on some chemical properties of superior grapes during 2015 and 2016 seasons.

\begin{tabular}{|l|c|c|c|c|c|c|c|c|}
\hline \multirow{2}{*}{ Treatment } & \multicolumn{2}{|c|}{ TSS \% } & \multicolumn{2}{c|}{ Total acidity \% } & \multicolumn{2}{c|}{ TSS/acid } & \multicolumn{2}{c|}{$\begin{array}{c}\text { Reducing sugar } \\
\text { \% }\end{array}$} \\
\cline { 2 - 9 } & $\mathbf{2 0 1 5}$ & $\mathbf{2 0 1 6}$ & $\mathbf{2 0 1 5}$ & $\mathbf{2 0 1 6}$ & $\mathbf{2 0 1 5}$ & $\mathbf{2 0 1 6}$ & $\mathbf{2 0 1 5}$ & $\mathbf{2 0 1 6}$ \\
\hline Control & 14.46 & 14.73 & 0.638 & 0.655 & 20.66 & 22.49 & 11.43 & 11.29 \\
\hline Dormex 5\% & 17.40 & 17.20 & 0.522 & 0.540 & 33.33 & 31.85 & 13.96 & 13.53 \\
\hline Fructose 3\% & 16.28 & 16.10 & 0.540 & 0.548 & 30.15 & 29.38 & 12.95 & 12.32 \\
\hline Fructose 5\% & 15.84 & 15.44 & 0.581 & 0.584 & 27.26 & 26.44 & 12.68 & 12.08 \\
\hline Methionine 3\% & 15.62 & 15.48 & 0.587 & 0.603 & 26.61 & 25.67 & 12.44 & 12.11 \\
\hline Methionine 5\% & 16.22 & 15.90 & 0.565 & 0.582 & 28.71 & 27.32 & 12.76 & 12.30 \\
\hline LSD at 5\% & 0.46 & 0.39 & 0.033 & 0.038 & 3.26 & 3.81 & 0.56 & 0.64 \\
\hline
\end{tabular}

\section{Bud hormonal content:}

Data in Table (6) and Figure (1) showed the effect of dormex, methionine and fructose spraying on bud hormonal content. In a general view, it can be seen that all treatments induced a gradually significant increase in the contents of indole-3-acetic acid (IAA) and gibberellic acid $\left(\mathrm{GA}_{3}\right)$ and gradually significant decrease in abscisic acid (ABA) in buds of "Superior" grapevines from treated date towards to bud burst as compared with the vines that were sprayed with tap water (control). The obtained bud contents of IAA and $\mathrm{GA}_{3}$ with dormex or fructose $3 \%$ surpassed their contents recorded with all other treatments in all the sampled dates. Maximum contents of IAA and $\mathrm{GA}_{3}$ were obtained from buds treated with dormex, collected in 18 February, while minimum contents were recorded on untreated buds, sampled in 7 January. For ABA, the opposite situation was found. Maximum contents of IAA and $\mathrm{GA}_{3}$ and minimum of ABA were obtained from buds treated with dormex, while minimum and maximum contents were obtained from unsprayed vines (control), respectively. No significant differences were detected among dormex and fructose at $3 \%$ effects. 
Table 6. Effect of dormex, fructose and methionine spraying on hormonal content of buds of superior grapevines during 2015 and 2016 seasons.

\begin{tabular}{|c|c|c|c|c|c|c|c|c|}
\hline \multirow{3}{*}{ Treatment } & \multicolumn{8}{|c|}{ Sample date } \\
\hline & 2015 & 2016 & 2015 & 2016 & 2015 & 2016 & 2015 & 2016 \\
\hline & \multicolumn{2}{|c|}{7 Jan. } & \multicolumn{2}{|c|}{21 Jan. } & \multicolumn{2}{|c|}{4 Feb. } & \multicolumn{2}{|c|}{18 Feb } \\
\hline \multicolumn{9}{|c|}{ Indole acetic acid (IAA) $\left(\mu g^{-1} \mathrm{DW}\right)$} \\
\hline Control & 0.553 & 0.571 & 0.746 & 0.768 & 0.883 & 0.918 & 0.966 & 0.993 \\
\hline Dormex & 0.876 & 0.912 & 1.010 & 1.054 & 1.236 & 1.256 & 1.910 & 1.953 \\
\hline Fructose 3\% & 0.796 & 0.811 & 0.938 & 0.973 & 1.148 & 188 & 1.756 & 1.864 \\
\hline Fructose 5\% & 0.718 & 0.765 & 0.870 & 0.961 & 1.057 & 1.089 & 1.672 & 1.708 \\
\hline Methionine 3\% & 0.740 & 0.768 & 0.875 & 0.908 & 1.006 & 1.038 & 1.640 & 1.689 \\
\hline Methionine 5\% & 0.760 & דינון & J & .000 & 0.998 & 1.029 & .486 & 1.516 \\
\hline LSD at $5 \%$ & 14 & 0.108 & 0.092 & 0.104 & 0.106 & 0.093 & 0.168 & 0.118 \\
\hline \multicolumn{9}{|c|}{ Gibberellic acid (GA) $\left(\mu \mathrm{g}^{-1} \mathrm{DW}\right)$} \\
\hline Con & 0.643 & 0.660 & 0.718 & 0.740 & 0.940 & 0.966 & 0.933 & 0.952 \\
\hline Dormex 5\% & 0.800 & 0.000 & 0.920 & 0.947 & $1.1 / 1$ & 1.198 & 1.190 & 1.215 \\
\hline Fructose 3\% & 0.783 & 0.804 & 0.897 & 0.922 & 1.152 & 1.187 & 1.140 & 1.138 \\
\hline Fructose 5\% & 0.756 & 0.188 & 0.833 & 0.859 & 1.050 & 1.063 & 1.066 & 1.083 \\
\hline Methionine 3\% & 0.748 & 0.781 & 0.886 & 0.916 & 1.058 & 1.086 & 1.082 & 1.108 \\
\hline Methionine 5 & 0.806 & 0.836 & 0.857 & 0.882 & 1.089 & 1.182 & 1.130 & 1.152 \\
\hline LSD at 5\% & 0.102 & 0.115 & 0.110 & 0.093 & 0.083 & 0.089 & 0.077 & 0.121 \\
\hline \multicolumn{9}{|c|}{ Abscisic acid (ABA) $\left(\mu g^{-1} D W\right)$} \\
\hline Control & 2.033 & 1.998 & 3.100 & 3.025 & 2.200 & 2.181 & 1.333 & 1.312 \\
\hline Dormex 5\% & 1.716 & 1.689 & 2.500 & 2.450 & 1.733 & 1.698 & 0.966 & 0.948 \\
\hline Fructose 3\% & 1.600 & 1.582 & 2.533 & 2.480 & 1.503 & 1.476 & 0.979 & 0.966 \\
\hline Fructose 5\% & 1.766 & 1.726 & 2.566 & 2.486 & 1.900 & 1.873 & 1.066 & 1.049 \\
\hline Methionine 3\% & 1.603 & 1.575 & 1.963 & 1.925 & 1.883 & 1.859 & 1.001 & 0.984 \\
\hline Methionine 5\% & 1.620 & 1.598 & 2.510 & 2.478 & 1.850 & 1.824 & 0.992 & 0.968 \\
\hline LSD at $5 \%$ & 0.253 & 0.262 & 0.384 & 0.352 & 0.277 & 0.264 & 0.308 & 0.234 \\
\hline
\end{tabular}



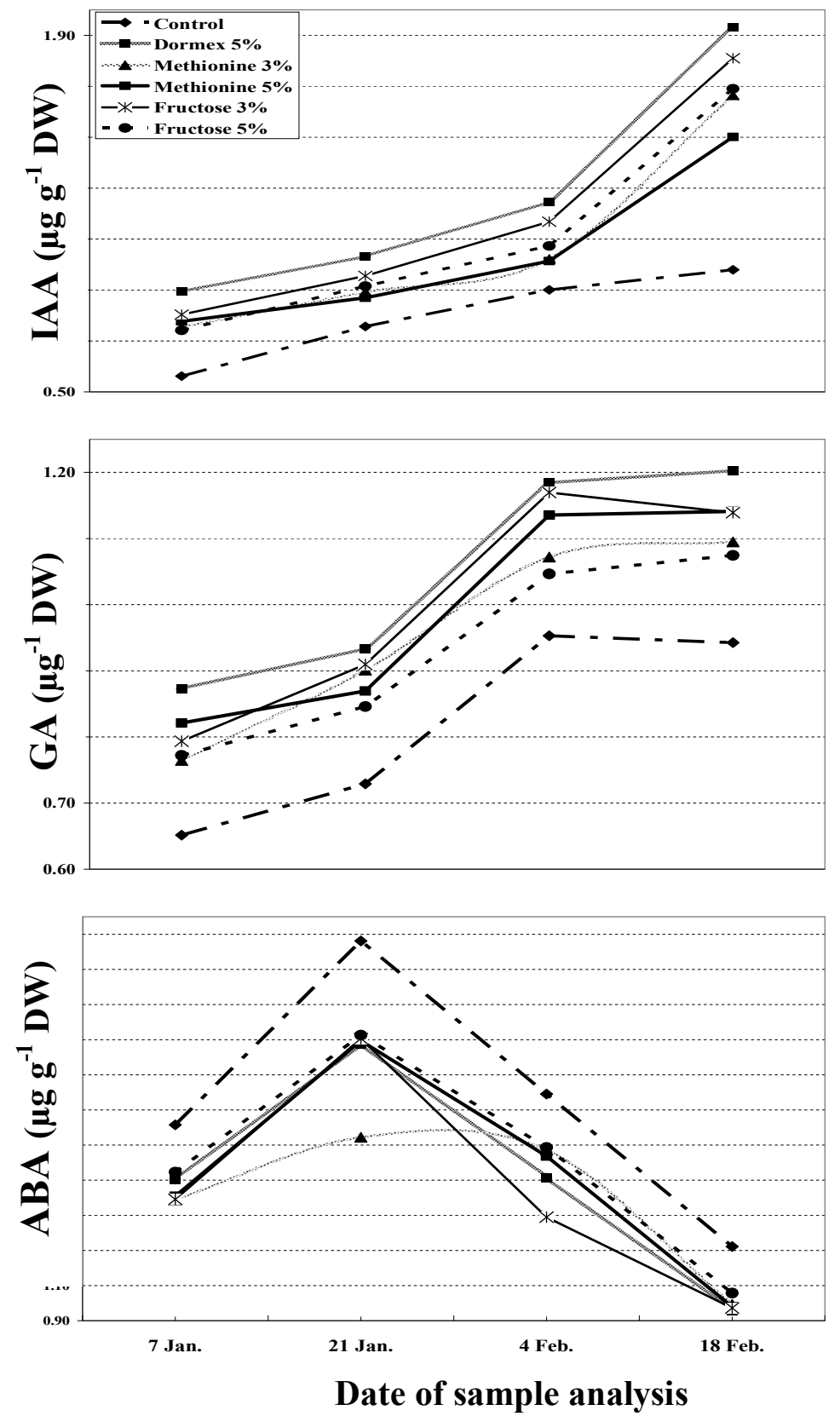

Fig. 1. Effect of dormex, fructose and methionine spraying on hormonal content of buds of superior grapevines, as mean of 2015 and 2016 seasons.

\section{Discussion}

Many changes in some chemical components in floral buds, particularly the contents of endogenous hormones (IAA, $\mathrm{GA}_{3}$ and $\mathrm{ABA}$ ) found to occur for playing a vital role in regulating dormancy and bud break. Several studies focused on the relationship between the endogenous hormones and/or amino acids and dormancy in buds (El-Sabrout, 1998; El-Sese and Mohamed, 2003 and Seif El-Yazal et al., 2012). Endogenous hormones help plants to respond to the environmental signals (Horvath et al., 2003). Endogenous gibberellins (GA's) play a role in many developmental processes and have been 
proved to participate in the regulation of dormancy (Wang et al., 2006). The present results showed that growth-promoting hormones $\left(\mathrm{GA}_{3}\right.$ and IAA) found to be gradually increased, but growth-inhibiting hormones (ABA) decreased during bud break (Table 6). This suggested that higher IAA and $\mathrm{GA}_{3}$ contents and lower ABA content were needed for release of "Superior" grapevine buds from dormancy.

The positive action of dormex on breaking dormancy and fruiting is mainly attributed to its effect in removing buds scales, reducing ABA, catalase, reduced and oxidized glutathione and enhancing free water, IAA, $\mathrm{GA}_{3}$, cytokinins, soluble sugars, amino acids, total indoles, oxidative stress, $\mathrm{H}_{2} \mathrm{O}_{2}$, total free polyamines and respiratory key enzymes activities (Wood, 1983 and Seif-El-Yazal and Rady, 2013). The decrease in ABA level as the chilling accumulation is increased in some grape cultivars. Hence, it is likely that the sugars might influence $\mathrm{ABA}$ metabolism, which subsequently affected the bud dormancy (Poudel, 2008). Also, methionine may induce bud break through the production of ethylene that is considered to affect dormancy release in plant species (Keegan et al., 1989).

In addition, the increasing of yield may be due to the effect of treatments in increasing the percentage of fruiting buds, Table (2) surely reflects the increasing of the number of cluster per treated vine which consequently increased the yield/vine. As well as, the effects of dormex and fructose on improving berry quality that could be mainly due to its effect on advancing bud burst and consequently all subsequent stages of early growth cycle and advancing maturity.

The results revealed that sugars may be used as bud break agents for breaking grape bud dormancy. Hence, $3 \%$ fructose solution showed a potential for use as a commercial bud break agent in the future.

The results in this connection were in agreement with those obtained by George and Nissen (1990), El-Sabrout (1998), El-Salhy (2002), Chaiwat et al. (2008), Sabry, Gehan et al. (2011), Madhab et al. (2011), Hatem et al. (2012), Seif El-Yazal and Rady (2013), Ahmed et al. (2014).

\section{Conclusion}

The best results with regard to breaking bud dormancy and improving yield and quality of "Superior" grapevines were obtained with spraying either dormex at $5 \%$ or fructose at $3 \%$.

Such results revealed that sugar may be used as a bud break agent for breaking grape bud dormancy. Solution of fructose at $3 \%$ had the greatest bud break inducing ability. Hence, $3 \%$ fructose solution shows potential for use as a commercial bud break.

\section{References}

Ahmed, F.F.; H.I.M. Ibrahim; M.A.M. Abada and M.M.M. Osman (2014). Using plant extracts and chemical rest breakages for breaking bud dormancy and improving productivity of superior grapevines growing under hot climates. World Rural Observations, 6(3): 8-18.

Arora, R.; L.J. Rowland and K. Tanino (2003). Induction and release of bud dormancy in woody perennials; a science comes of age. HortScience, 38: 911-921. 
Association of Official Agricultural Chemists (2000). Official Methods of Analysis (A.O.A.C.), $17^{\text {th }} \mathrm{Ed}$ Benjamin Franklin Station, Washington, D.C., U.S.A., pp. 490-510.

Chaiwat, P.; N. Fujioka; F. Fukuda and N. Kubota (2008). Physiological aspects of bud associated with breaking dormancy in grapevines scientific reports of the Faculty of Agriculture, Okayama University, 97: 41-47.

Dookoozlian, N. and E. Williams (1995). Chilling exposure and hydrogen cyanamide interact in breaking dormancy of grape buds. Hortic. Sci., 30: 1244-1247.

El-Sabrout, M.B. (1998). Some physiological and bio-chemical responses of Flame Seedless grapevines to hydrogen cyanamide (Dormex) spray. Alex. J. Agric. Res., 43 (3): 167-185.

El-Salhy, A.M. (2002). Improvement of bud burst, yield and berry quality of King's Ruby grapevines under warm climates by using dormex and ammonium nitrate spraying. Assiut J. Agric. Sci., 33 (2): 71-86.

El-Sese, A.M. and A.M. Mohamed (2003). Chilling, heat requirements and hormonal control in relation to bud dormancy in Red Roomy and Thompson Seedless grape cultivars (Vitis vinifera L.). Assiut J. Agric. Sci., 34 (6): 221-236.

Garlick, J.P. (2006). Toxicity of methionine in humans. The Journal of Nutrition, 136: 1722-1725.

George, A.P. and R.J. Nissen (1990). Effect of hydrogen cyanamide on yield, growth and dormancy release of table grapes in subtropical Australia. Acta Hort., 279: 427436.

Hatem, B.M.; A.M. Vadel; J.M.C. Geuns and H. Khemira (2012). Effects of hydrogen cyanamide on antioxidant enzymes' activity, proline and polyamine contents during bud dormancy release in Superior Seedless grapevine. Physiol. Plant 34: 429-437.

Horvath, D.P.; J.V. Anderson; W.S. Chao and M.E. Foley (2003). Knowing when to grow: signals regulating bud dormancy. Trends Plant Sci., 8: 534-540.

Keegan, A.B.; K.M. Kelly and J.V. Staden (1989). Ethylene involvement in dormancy release of Ricinodendron rautanenii seeds. Annals of Botany, 63: 229-234.

Kettner, J. and K. Doerffling (1995). Biosynthesis and metabolism of abscisic acid in tomato leaves infected with Botrytis cinerea. Planta 196: 627-634.

Lin, C. and T.Y. Wang (1985). Enhancement of bud sprouting in grape single bud cutting by cyanamide. Am. J. Enol. Viticult., 36: $15-17$.

Madhab, R.; R. Mochioka; K. Beppu; P.R. Poudel and I. Kataoka (2011). Effect of rare sugars, methionine, and sea water on "Kyoho" grape bud dormancy release. ASEV Jpn., 22 (3): 127-132.

Matsuo, T. and K. Izumori (2006). Effects of dietary D-psicose on diurnal variation in plasma glucose and insulin concentrations of rats. Biosci. Biotechnol. Biochem. 70: 2081-2085.

Mead, R.; R.N. Currnow and A.M. Harled (1993). Statistical methods in agriculture and experimental biology. Second Ed. Chapman \& Hall London, pp: 10-44.

Mohamed, A.K. and Y.A.M. Omran (2004). Chilling and heat requirements for bud brak and fruit development of some grape cultivars under Assiut codnitons. Assiut J. of Agric. Sci., 35 (3): 1-9.

Nir, G.; I. Klein; S. Lavee; G. Spieler and U. Barak (1988). Improving 
grapevine bud break and yields by evaporative cooling. J. Am. Soc. Hortic. Sci., 113: 512-517.

Poni, S.; I. Filippetti and A. Zanatti (1990). Effects of Dormex applications on Vitis vinifera (cv. Sangiovese) in a cold winter area. Advances in Hort. Sci., 4 (2): 121126.

Poudel, P.R. (2008). Evaluation and utilization of grape germplasms native to Japan. Doctoral Thesis, Ehime University, Japan.

Sabry, Gehan, H.; Hanaa A. El-Helw and Ansam S. Abd El-Rahman (2011). A study on using jasmine oil as a breaking bud dormancy for Flame Seedless Grapevines. Report and Opinion, 3 (2): 48-56.

Saure, M.C. (1985). Dormancy release in deciduous fruits tree. Hortic Rev., 7: 239-300.

Seif El-Yazal, M.A. and M.M. Rady (2013). Foliar-applied Dormex ${ }^{\mathrm{TM}}$ or thiourea-enhanced proline and biogenic amine contents and hastened breaking bud dormancy in "Ain Shemer" apple trees. Trees, 27: 161-169.

Seif El-Yazal, M.A., M.M. Rady and S.A. Seif (2012). Foliar-applied dormancy-breaking chemicals change in the content of nitrogenous compounds in the buds of apple (Malus sylvestris Mill. cv. Anna) trees. J. Hortic Sci. Biotechnol., 87: 299-304.
Settimi, L.; F. Davanzo; G. Miceli; D. Richmond and G.M. Calvert (2005). Update: Hidrogen cyanamide-related Ilnesses-Italy, Morbidity and Mortality Weekly Report. Atlanta, 54: 405-408.

Shulman, Y.; G. Nir; L. Fanberstein and S. Lavee (1983). The effect of cyanamide on release from dormancy of grapevine buds. Scientia Hort., 19: 97-104.

Trejo-Martinez, M.A.; J.A. Orozco; G. Almaguer-Vargas; E. CarvajalMillan and A.A. Gardea (2009). Metabolic activity of low chilling grapevine buds forced to break. Thermochim Acta, 481: 28-31.

Wang, H.B.; D.S. Gao; X.D. Wang and J. Li (2006). Role of gibberellin and abscisic acid in peach bud endodormancy induction. J. Fruit Sci., 23: 599-601.

Weaver, R.J (1976). Grape growing. Univ. of Calif. Davis, pp. 106-174.

Wood, B.W. (1983). Changes in indole acetic, abscisic acid, gibberellins and cytokinins during bud break in pecan. J. Amer. Soc. Hort. Sci., 108 (2): 333-338.

Zelleke, A. and W. Kliewer (1989). The effects of hydrogen cyanamide on enhancing the time and amount of bud break in young grape vineyards. Am. J. Enol. Viticult. 40: 47-51. 
تأثير رش الدورميكس والفركتوز و الميثونين علي كسر سكون براعم شجيرات العنب

\section{السويريور}

أسماء أحمد محمد' ، فاطمه الزهراء محمد عبد الله جوده'

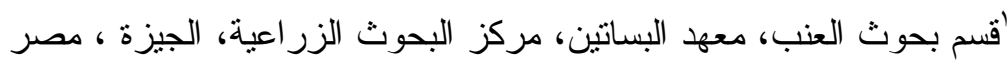

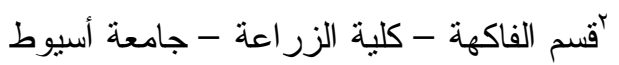

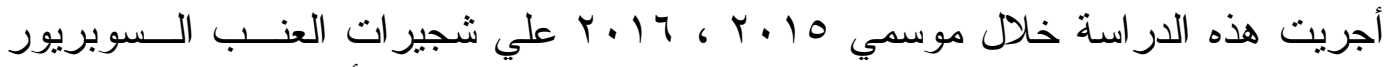

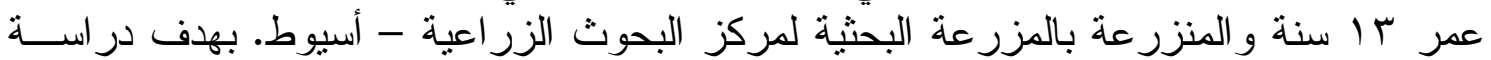

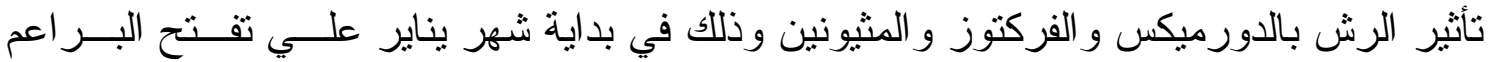

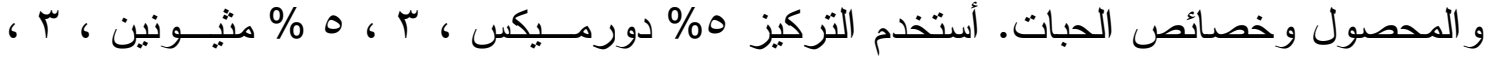

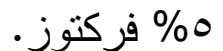

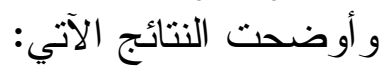

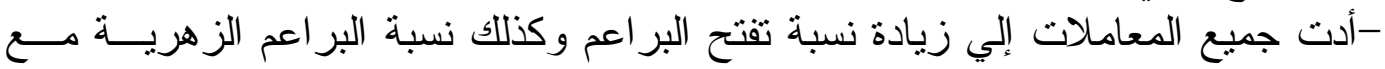

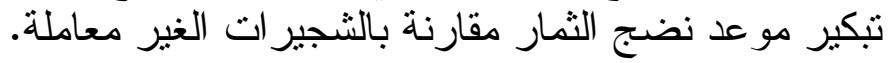

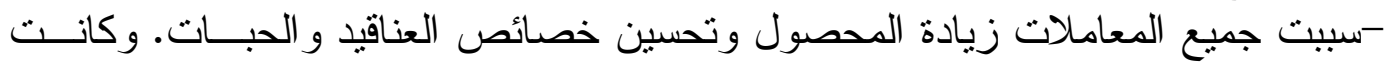
أفضل المعاملات رش ه\% دورميكس. ولم تسجل فروق معنوية بين الرش بالدورميكس 0\% أو أو

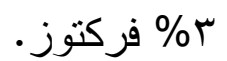

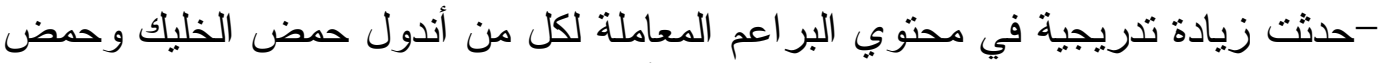

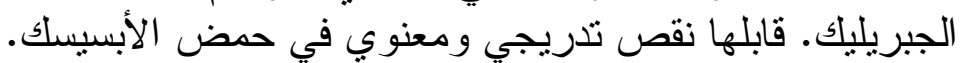

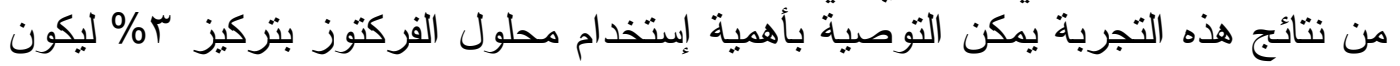

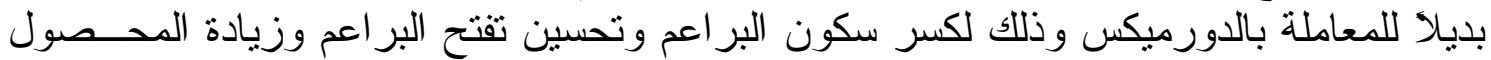
وتبكير النضج إضافة إلي المحافظة علي الثجير ات و البيئة. 